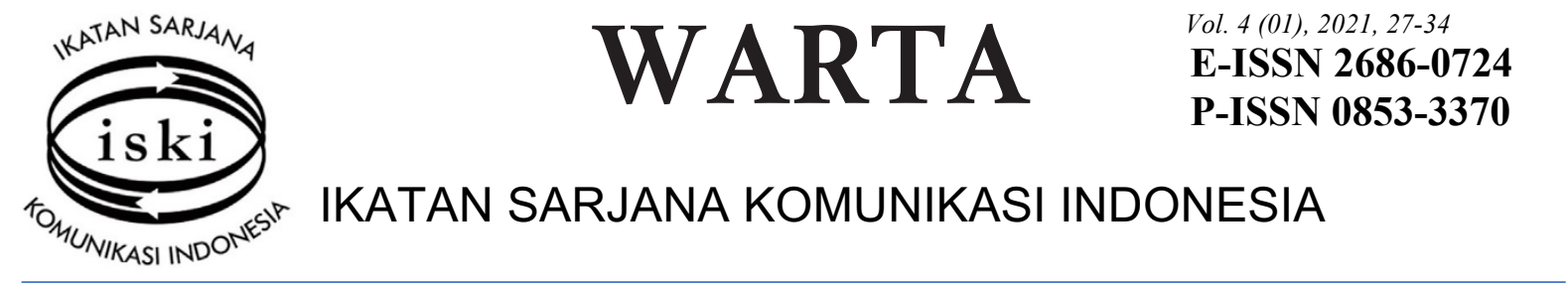

\title{
Instagram sebagai Pembentuk Citra Diri Generasi Milenial Jakarta
}

\author{
http://dx.doi.org/10.25008/wartaiski.v4i1.73 \\ Clarissa Maureen ${ }^{1}$, Yolanda Stellarosa ${ }^{2}$ \\ ${ }^{1,2}$ Institut Komunikasi dan Bisnis LSPR \\ Jl. KH Mas Mansyur Kav. 35, Jakarta 10220, Indonesia \\ e-mail korespondensi: yolanda.s@1spr.edu
}

Submitted: 26/02/2021, Revised: 28/05/2021, Accepted: 15/06/2021

Accredited by Kemristekdikti No. 30/E/KPT/2019

\begin{abstract}
The development of social media makes it easy for the community or its users to communicate without limits in space and time. Instagram is a platform that is widely used by millennials today. This study aims to determine the use of Instagram social media in the formation of millennial generation self-image in Jakarta using the symbolic interaction theory. This research uses qualitative methods with interview techniques conducted in Jakarta and four representatives of the millennial generation act as the main sources of information in this study. The results of the study show that in shaping the image of itself on Instagram's social media, millennials created symbols, such as the colour tone in their photos and the casual language style which convey an image of millennials being unique, confident, creative, and connected individuals who are able to interact with others through social media.
\end{abstract}

Keywords: Self image; social media; instagram; millennial generation

\begin{abstract}
Abstrak
Berkembangnya media sosial memudahkan masyarakat atau para penggunanya dalam melakukan komunikasi tanpa batas ruang dan waktu. Instagram merupakan salah satu platform yang banyak digunakan oleh generasi milenial saat ini. Penelitian ini bertujuan untuk memahami penggunaan media sosial Instagram dalam pembentukan citra diri generasi milenial di Jakarta dengan menggunakan teori interaksi simbolik. Penelitian ini menggunakan metode kualitatif dengan teknik wawancara yang dilakukan di Jakarta kepada empat perwakilan generasi milenial sebagai informan utama dalam penelitian ini. Hasil penelitian menunjukan bahwa dalam membentuk citra dirinya di media sosial Instagram, generasi milenial menciptakan simbol-simbol seperti melalui tone warna pada foto-fotonya dan gaya bahasa yang santai sehingga terbentuklah sebuah citra tertentu; bahwa generasi milenial merupakan seorang individu yang unik, percaya diri, kreatif, dan connected di mana mereka mampu berinteraksi dengan orang lain melalui media sosial.
\end{abstract}

Kata kunci: Citra diri; media sosial; instagram; generasi milenia

\section{PENDAHULUAN}

Penggunaan teknologi internet saat ini banyak dimanfaatkan oleh masyarakat untuk berbagai kepentingan. Sebagai suatu teknologi, internet dapat memunculkan jenis interaksi baru yang berbeda dengan interaksi sosial sebelumnya. Jika dahulu masyarakat bertatap muka, kini masyarakat berinteraksi di dunia maya. Hal itu dapat dilihat dari data yang disampaikan Henri Kasyfi, Sekjen Asosiasi Penyelenggara Jasa Internet Indonesia (APJII), sebanyak 171,17 juta dari total populasi Indonesia terhubung di Internet dengan penetrasi internet terbesar di Pulau Jawa (Pramono, 2019). 


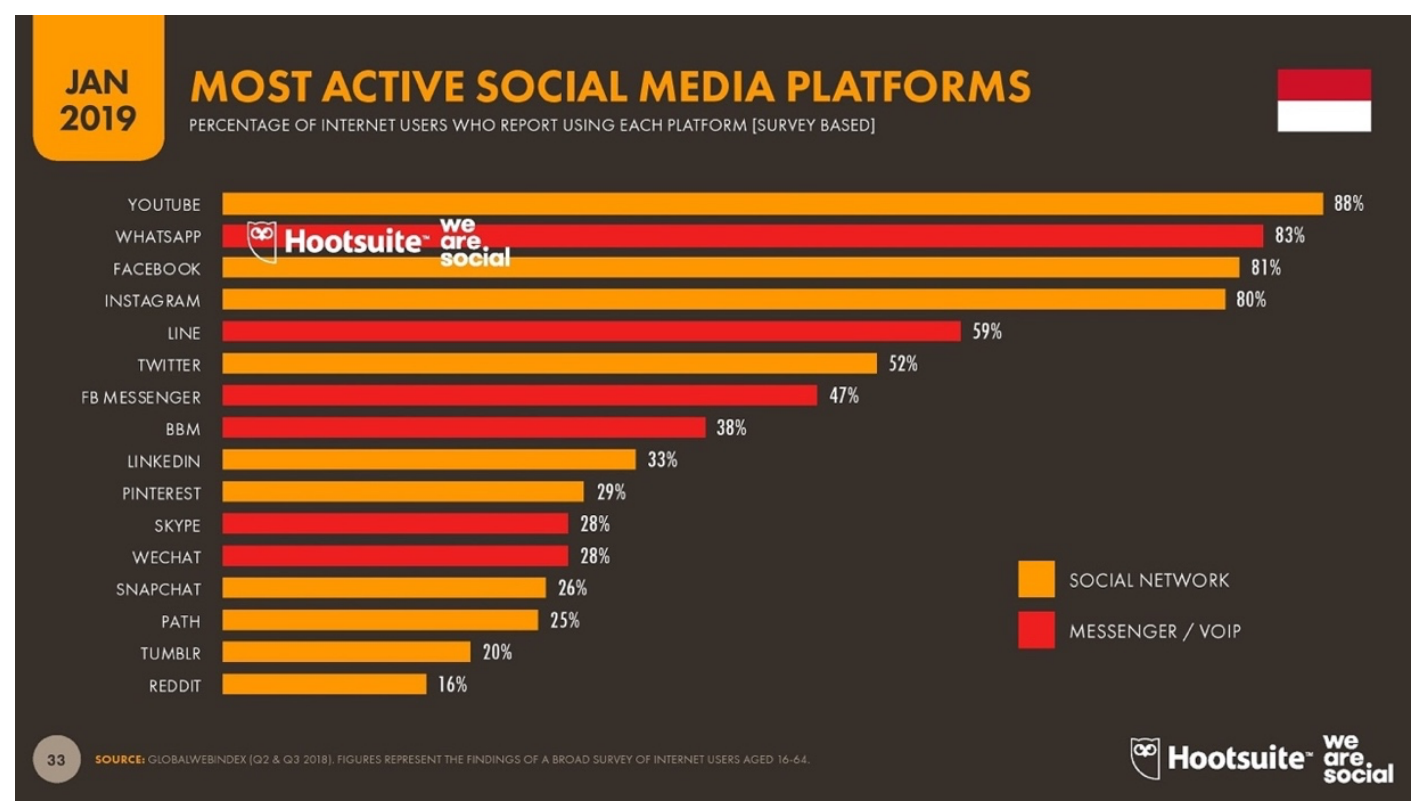

Gambar 1. Most Active Social Media Platforms Sumber: We Are Social (2019)

Perkembangan internet yang begitu pesat bermanfaat bagi masyarakat dalam bermedia sosial. Media sosial merupakan sebuah media yang dapat memberikan ruang untuk berinteraksi dalam jejaring sosial (Nasrullah, 2015). Berdasarkan penelitian Wahyudin, Ronauli, Elita, dan Mirawati (2016), ruang interaksi dalam jejaring sosial ditunjukkan melalui pesan yang disampaikan, dan berpengaruh terhadap sikap maupun gaya hidup masyarakat. Kaplan dan Haelein (2010) mengemukakan, media sosial adalah aplikasi berbasis internet dan teknologi Web 2.0 yang memungkinkan pertukaran user generated content (Nugraha \& Akbar, 2018).

Pengguna media sosial di Indonesia menduduki peringkat keempat terbesar di dunia (Arifin, 2019). Berdasarkan data dari We Are Social (2019), pengguna internet di Indonesia menghabiskan waktu 8 jam 36 menit dalam sehari. Waktu yang digunakan untuk bermedia sosial sebanyak 3 jam 26 menit. Paul Webster, Brand Development Lead Instagram APAC mengatakan, dari 100 juta pengguna yang telah bergabung di media sosial Instagram, lebih dari setengahnya bertempat tinggal di Asia dan Eropa. Di Indonesia pengguna Instagram mencapai 89 persen (Mailanto, 2016).

Berdasarkan pengelompokan media sosial dari Mayfield (2008), Instagram masuk dalam kelompok media sosial jenis content communities. Media sosial buatan Kevin Systrom dan Mike Krieger itu merupakan aplikasi yang memiliki fitur efek foto yang menjadi karakteristiknya hingga terjadi partisipasi (participation), keterbukaan (openned), percakapan (conversation), komunitas (community), dan connectedness atau keterhubungan (Nugraha \& Akbar, 2018). Saat ini, Instagram tidak hanya dimanfaatkan untuk berbagi informasi melainkan juga sebagai ajang mengelola kesan dan mempresentasikan diri di masyarakat (Mutia, 2017).

Berdasarkan penelitian Alvara Research Center (2014), konsumsi internet kelompok usia 15 sampai 34 tahun jauh lebih tinggi dibandingkan dengan kelompok usia yang lebih dewasa. Hal itu menunjukkan, ketergantungan generasi milenial terhadap internet sangat tinggi. Generasi milenial atau generasi Y, merupakan generasi yang lahir tahun 1981 hingga tahun 2000. Saat ini generasi tersebut menjadi perhatian di berbagai bidang (Young, Sturts, Ross, \& Kim, 2013). Hasil survei Asosiasi Penyelenggara Jasa Internet Indonesia (APJII) bekerjasama dengan Pusat Kajian dan Komunikasi Universitas Indonesia (Puskakom UI) menyatakan, di tahun 2014 jumlah pengguna internet di Indonesia didominasi pengguna berusia 18 sampai 25 tahun (49 persen). Jadi, dapat dikatakan generasi yang lahir di tahun 1980-an masuk kategori digital natives (Dwilestari \& Fithrah, 2018).

Kehadiran media sosial Instagram di kalangan milenial membuat ruang pribadi seseorang melebur dengan ruang publik. Mereka tidak segan-segan mengunggah kegiatan pribadinya untuk disampaikan kepada teman-temannya melalui akun media sosial Instagramnya dalam upaya membentuk citra diri. Merujuk penelitian Safitri dan Ramadanty (2019), kemampuan Instagram untuk mempublikasikan 
konten berupa foto, teks dan video yang dapat diedit langsung, menjadi suatu kemudahan bagi pengguna untuk menyajikan unggahan yang sesuai dengan keinginan. Hal inilah yang membuat kalangan milenial maupun masyarakat pada umumnya tertarik menggunakan Instagram.

Maraknya aplikasi berbasis chat saat ini, membentuk diri generasi milenial memiliki 'wajah' atau pembawaan yang berbeda-beda saat melakukan chatting dengan group chat satu dan lainnya. Fitur-fitur media sosial memudahkan generasi milenial dalam mengunggah segala sesuatu seperti makanan, produk bermerek, dan lain sebagainya (Srinanda, 2019:318). Ali dan Purwandi (2017) berpendapat, perilaku tersebut dikategorikan dalam tiga jenis yaitu: (1) two faces of solidarity, generasi milenial yang peduli dengan isu-isu sosial, (2) sharing is better, senang berbagi informasi, dan (3) followers is family, mempunyai sikap solidaritas yang tinggi dengan para pengikutnya.

Berdasarkan hasil survei di Inggris, sebesar 53\% milenial muda lebih menyukai mengunggah foto mereka di media sosial dan hanya $13 \%$ yang memiliki album foto. Selfie kini menjadi pose paling populer di kalangan milenial. Sekitar 30\% dari foto-foto yang mereka miliki merupakan foto selfie (Yuswohady, 2019:78). Psikolog Ratim Ibrahim (dalam Arviana, 2017) mengatakan, generasi milenial merupakan generasi "Look at Me", yaitu generasi yang memiliki rasa narsis tinggi, disebut Narcissistic Personality Disorder (NPD) yakni kelainan seseorang yang mencintai dirinya secara berlebihan dan dapat dilihat dari perasaan ketika mendapatkan sedikit like, comment, maupun follower (Arviana, 2017). Di sisi lain Yuswohady (2019) mengatakan, generasi milenial telah kehilangan keahlian sosial dasar karena keberadaan teknologi. Generasi tersebut tidak peduli dengan jabat tangan, memainkan intonasi pengucapan, dan lain sebagainya.

Generasi milenial terbentuk dari beberapa pandangan. Di satu sisi, generasi tersebut memiliki rasa narsis yang tinggi dan di sisi lain, generasi tersebut dianggap sebagai generasi santai, tidak mau terikat, dan lain sebagainya. Oleh sebab itu, penelitian ini bertujuan untuk mengetahui dan mendeskripsikan penggunaan media sosial Instagram dalam pembentukan citra diri generasi milenial di Jakarta mulai dari proses awal yang dilakukan generasi milenial sampai terbentuknya sebuah citra diri melalui media sosial Instagram.

\section{KERANGKA TEORI}

Citra dapat dikatakan sebagai cerminan dari identitas sebuah organisasi atau bagaimana suatu organisasi dipandang; sedangkan citra diri yang menjadi fokus dalam penelitian ini dapat diartikan sebagai jati diri seperti yang digambarkan atau yang dibayangkan dikemudian hari (Chaplin, 2011). Citra diri dalam penelitian ini merujuk pada pandangan seseorang mengenai dirinya sendiri atau dikenal dengan istilah Self-Concept (konsep diri). Konsep diri akan membentuk keunikan tertentu yang dimiliki oleh individu tersebut, yang akan menjadi pembeda dan membuat dirinya semakin mudah diingat oleh orang lain (Loretta, 2015).

Penelitian ini fokus pada citra atau konsep diri yang dibentuk oleh generasi milenial. Generasi milenial merupakan suatu kelompok yang lahir saat perkembangan teknologi semakin pesat, segala sesuatunya menggunakan smartphone. Berdasarkan Generation Theory yang dicetuskan Karl Mannheim (1923) generasi milenial merupakan generasi yang lahir pada tahun 1980 sampai dengan 2000. Kisaran usia generasi milenial di tahun 2020 adalah 20 hingga 40 tahun. Ciri-ciri yang dimiliki generasi milenial ditandai dengan peningkatan penggunaan dan keakraban dengan komunikasi, media, dan teknologi digital (Badan Pusat Statistik, 2018).

Citra atau identitas diri tertentu yang dibentuk oleh generasi milenial dapat dilakukan melalui media sosial. Media sosial merupakan alat atau sarana yang digunakan untuk menyampaikan pesan dari komunikator kepada masyarakat. Persepsi masyarakat dapat terbentuk dengan menggunaka media komunikasi baik media massa cetak maupun digital seperti Instagram. Media sosial disebut juga sebagai media online yang dapat memudahkan para penggunanya berpartisipasi, berbagi, dan menciptakan isi seperti blog, forum dan dunia virtual (Cahyono, 2016).

Merujuk pada penelitian yang dilakukan Ayun (2015), media sosial merupakan medium yang digunakan remaja membentuk identitas diri; menunjukkan identitas yang berbeda di media sosial dan mengekspresikan masalah pribadi dalam bentuk tersirat.

Media sosial digunakan dalam pembentukan identitas diri juga diperkuat penelitian yang dilakukan oleh Sakti dan Yulianto (2018): remaja saat ini memanfaatkan Instagram sebagai sarana dalam mencari dan membentuk jati diri dengan memanfaatkan berbagai fasilitas atau fitur yang ada di Instagram. 
Pembentukan citra atau identitas diri yang dibentuk melalui penggunaan Instagram ini dilihat dari beberapa konsep dari interaksi simbolik yaitu: (1) proses pikiran (mind) dalam penggunaan Instagram; George Herbert Mead mengatakan, pikiran merupakan sebuah kemampuan untuk menginterpretasikan simbol dengan makna yang sama. Simbol dapat digambarkan seperti bahasa atau simbol signifikan (significant symbol), memunculkan makna yang sama bagi banyak orang. Mead memiliki paham bahwa manusia perlu mengembangkan pikirannya atau mind melalui interaksi bersama orang lain dengan bahasa yang digunakan bersama orang lain menjadi salah satu simbol pendukung dari pikiran; (2) Diri (self), dibentuk oleh seseorang yang dalam penelitian ini adalah generasi milenial. George Herbert Mead mengemukakan, diri (self) merupakan suatu kemampuan untuk merefleksikan diri sendiri berdasarkan perspektif orang lain. Mead meminjam konsep Charles Cooley pada tahun 1912. Ia mengatakan, pengambilan peran khusus dan melihat diri dari perspektif orang lain sebagai cermin diri (looking-glass self). Cooley menyakini tiga prinsip pengembangan yang dihubungkan dengan cermin diri: seseorang membayangkan bagaimana ia dilihat orang lain; seseorang membayangkan penilaian orang lain terhadap dirinya; dan perasaan sakit atau bangga yang diterimanya berdasarkan perasaan dari apa yang ia pikirkan mengenai perspektif orang lain tersebut; (3) Masyarakat (society) yang memaknai citra diri dari generasi milenial (West \& Turner, 2008:104-107).

Dengan demikian, makna terkait citra diri seseorang muncul sebagai hasil interaksi di antara manusia baik secara verbal maupun nonverbal. Dalam hal ini makna dalam perilaku manusia, konsep diri dan hubungan antar individu dengan masyarakat.

\section{METODE PENELITIAN}

Penelitian ini menggunakan metode penelitian deskriptif kualitatif. Sugiyono (2016) mengatakan, metode penelitian kualitatif merupakan metode penelitian yang berlandaskan pada filsafat postpositivisme. Creswell (2014) mengungkapkan, dalam penelitian kualitatif terdapat delapan karakteristik: (1) penelitian dilakukan dalam lingkungan yang alami, (2) peneliti sebagai instrumen penelitian, (3) menggunakan berbagai macam sumber data, (4) analisis data dilakukan secara induktif dan deduktif, (5) penekanan pada pemaknaan narasumber, (6) Emergent Design, (7) refleksivitas, dan (8) penelitian dilakukan secara holistik.

Informan penelitian ini adalah empat remaja yang mewakili generasi milenial, berusia antara 20 sampai 40 tahun, aktif menggunakan media sosial Instagram. Penelitian ini fokus pada generasi milenial yang menggunakan media sosial Instagram tidak sebagai ladang pekerjaan.

Teknik pengumpulan data menggunakan semistructure interview dan studi kepustakaan. Teknik Analisis Data menggunakan model Miles dan Huberman, dilakukan dalam analisis kualitatif bersifat interaktif dan berlangsung terus menerus Sugiyono (2016).

Penelitian ini menggunakan triangulasi sumber, yakni membandingkan data primer hasil wawancara yang dilakukan pada informan dengan data sekunder yaitu studi kepustakaan serta hasil wawancara dengan pengamat generasi milenial.

\section{HASIL PENELITIAN}

Generasi milenial merupakan sekelompok penduduk yang lahir antara 1980 sampai 2000-an. Bedasarkan Survei Sosial Ekonomi Nasional (Susenas) di tahun 2017, sebanyak 33,75\% atau 88 juta jiwa merupakan generasi milenial, disusul dengan generasi pasca milenial atau generasi $\mathrm{Z}$ sebanyak 29,23\% (Badan Pusat Statistik, 2018).

Lembaga Survei Sosial Ekonomi Nasional menyatakan terjadi peningkatan dalam penggunaan internet pada generasi milenial. Tahun 2015 jumlah generasi milenial yang menggunakan internet sebanyak 40,78\% dan tahun 2017 jumlah itu meningkat menjadi 56,42\% (Badan Pusat Statistik, 2018).

Keberadaan website, email, blog, chatroom, dan social media memudahkan generasi milenial dalam menuangkan ide-ide kreatifnya dan menyampaikannya kepada siapa pun, kapan pun, dan di mana pun. Merujuk penelitian Yunus dan Gustina (2018), hampir setiap hari generasi milenial menggunakan internet khususnya media sosial dengan waktu antara 15 sampai 60 menit sekali mengakses.

Berdasarkan Lembaga Survei Sosial Ekonomi Nasional 2017, sebanyak 83,23\% generasi milenial mengakses internet untuk menggunakan media sosial, 68,01\% untuk mendapatkan informasi, dan 46,81\% untuk hiburan (Badan Pusat Statistik, 2018). Penelitian Dwilestari dan Ali (2018), menunjukkan terdapat beberapa motif atau alasan dalam menggunakan media sosial: (1) kebutuhan untuk mengekpresikan diri di media sosial, (2) kebutuhan berinteraksi sosial dan menciptakan 
hubungan pertemanan dengan pengguna lainnya, dan (3) kebutuhan mendapatkan hiburan saat memiliki waktu kosong atau luang sehingga dapat menghilangkan atau melepaskan kejenuhan atau rasa bosan.

Generasi milenial merupakan generasi yang akrab dengan teknologi digital karena dibesarkan oleh kemajuan teknologi. Generasi ini juga akrab dengan penggunaan media sosial Instagram. Keberadaan internet dianggap efektif dan memudahkan generasi milenial untuk berselancar di media sosial. Hal ini diungkapkan oleh para informan seperti pernyataan informan 1 sebagai berikut:

\begin{abstract}
"Kalau aku kan, anak rantau ya jadi enak banget apalagi kalau orang tua kasih kabar atau aku yang kasih kabar ke orang tua atau mungkin aku lagi sakit. Itu jadi gampang ngabarinnya. Bayangin kalau gak ada internet, kita mau ngabarin orang tua, kita sakitnya hari ini trus suratnya baru sampai bulan depan atau kapan kan telat gitu ya. Jadi dengan adanya komunikasi ini memudahkan banget untuk komunikasi jarak jauh atau mungkin komunikasi sama teman ngomongin tugas dan lainnya."
\end{abstract}

Selain itu keberadaan internet semakin berkembang di saat pandemi Covid 19 saat ini. Pada masa Pembatasan Sosial Berskala Besar, dengan adanya internet dapat memudahkan mencari berbagai informasi secara cepat. Kehadiran internet juga memudahkan generasi milenial untuk menjangkau orang-orang secara luas dan berinteraksi dengan individu dari berbagai negara.

Media sosial Instagram menjadi salah satu platform yang paling sering digunakan oleh generasi milenial. Instagram merupakan sebuah media yang menyediakan berbagai informasi dan juga sebagai kanvas diri dari generasi milenial. Hal tersebut disampaikan oleh informan 3 sebagai berikut:

\begin{abstract}
"Ada dua sih yang paling aku highlight. Pertama tuh dalam segi komunikasi dalam bentuk kita memberikan informasi ataupun kita menerima informasi karena aku orangnya tuh paling jarang juga sih baca berita meskipun ya, seorang PR seharusnya baca berita banyak tapi kenyataannya gak sesering itu baca berita koran atau mungkin online media. Malahan selalu dapat update terbaru dari situasi apapun yang terjadi di Jakarta atau bahkan di dunia dari Instagram. Kedua, Instagram juga jadi kanvas diri kita di mana kita dapat mengekspresikan diri kita dan juga gain self confidence kita."
\end{abstract}

Dalam menyimpan foto-foto, generasi milenial menyimpannya di telepon selular daripada di album foto karena mencetak sebuah foto perlu biaya namun tidak bertahan lama karena foto tersebut dapat luntur atau rusak. Menyimpan foto di telepon selular memang memiliki risiko: ketika mengalami kerusakan maka semua data akan hilang. Namun saat ini tersedia berbagai platform menyimpan data seperti Dropbox, Google Drive. Ada juga beberapa foto yang diunggah di Instagram pribadi agar dapat berbagi momen-momen yang memorable dengan para pengikutnya.

Media sosial Instagram juga dapat dijadikan sebagai album foto baik pada Instagram feed maupun pada fitur archieve. Generasi milenial sering menggunakan fitur-fitur lainnya seperti follow, like, comment, dan mention untuk berinteraksi satu sama lain. Dari beberapa fitur yang disediakan oleh Instagram, generasi milenial paling sering menggunakan fitur story, comment, dan direct message yang dapat mewakili keseluruhan aktivitasnya di media sosial Instagram. Direct message merupakan salah satu fitur yang paling sering digunakan generasi milenial untuk berhubungan dengan teman-temannya. Sedangkan Instagram story merupakan salah satu fitur yang berdurasi lima belas detik di mana generasi milenial sering menggunakannya untuk mengekpresikan dirinya dengan mudah.

Berbagai penggunaan media sosial khususnya Instagram tentunya mempunyai tujuan tertentu. Salah satunya adalah menentukan jati diri. Melalui pola unggahan individu tersebut dapat melihat seperti apa karakter yang dibentuk. Inilah yang disebut Instagram merupakan bagian dari alat untuk personal branding. Hal tersebut disampaikan oleh informan 5 sebagai berikut:

\footnotetext{
"Proses pembentukan diri yang baik adalah ketika dilakukan dengan cara yang natural, organik, dan konsisten. Itu aja kuncinya. Ketika seseorang menunjukkan identitasnya dengan konsisten, dengan terencana. Gak ada yang salah dengan Instagram karena Instagram hanya sebuah alat, sama seperti Linkedin, Facebook, atau apapun itu dan seperti layaknya senjata atau pisau, bisa digunakan untuk tujuan baik atau tujuan mencelakakan diri sendiri, Instagram juga seperti itu. Jadi tujuan orang menggunakan Instagram itu menentukan siapa jati dirinya dan kita bisa melihat karakter orang dengan bagaimana pola dia mem-posting sesuatu. Ada yang memposting tentang dirinya, dirinya, dan dirinya. Dia gak pernah mem-posting tentang kehidupan sosialnya, dia gak pernah mem-posting kehidupan keluarganya, tidak pernah mem-posting kegiatan di luar make up dan kecantikannya atau ada juga yang tidak mau mencerminkan siapa dirinya, dia selalu menggunakan identitasidentitas tertentu. Jadi itu sah-sah aja, gak ada masalah, it's a part of the new tools of personal branding."
} 
Dalam membentuk citra diri di media sosial Instagram, generasi milenial melakukan interaksi dengan diri sendiri terlebih dahulu. Mereka mempertimbangkan bagaimana dirinya akan dinilai oleh masyarakat dan tanggapan yang akan timbul. Melalui pertimbangkan tersebut, para informan mulai menciptakan simbol-simbol yang menjadi ciri khas dirinya seperti gaya bahasa yang digunakan yaitu gaya bahasa casual atau santai.

Simbol lain yang digunakan para informan sebagai ciri khasnya adalah melalui ukuran foto-foto yang akan diunggahnya secara konsisten. Simbol lain juga ditunjukkan dengan menggunakan emoticon seperti hati hitam, tersenyum, orang ketawa sampai menangis, dan bintang-bintang. Hal tersebut sesuai dengan konsep teori interaksi simbolik yaitu pikiran (mind) dari George Herbert Mead, bahwa manusia perlu mengembangkan pikirannya melalui interaksi bersama orang lain di mana bahasa yang digunakan bersama orang lain menjadi salah satu simbol pendukung.

Dalam menggunakan media sosial Instagram, para informan menggambarkan dirinya sebagai seorang individu yang aktif dalam berinteraksi, percaya diri, kreatif, dan menyenangkan. Hal ini didukung dengan pernyataan informan 1 sebagai berikut:

\begin{abstract}
"Kalau aku sih menggambarkannya jadi orang yang asik aja gitu, maksudnya kayak gara-gara postingan kebanyakan yang lucu-lucu jadi kan orang kayak - eh gila ya selalu nge-post-nya yang kocak-kocak gitu. Jadi kayak anak yang asik, fun bukan yang kayak suka pamer harta atau gimana, ya cukup dengan fun gitu aja"
\end{abstract}

Selain itu juga ada sebagian generasi milenial yang mendefinisikan dirinya sebagai food blogger, travel blogger, atau beauty enthusiast; seperti dinyatakan oleh para informan. Hal tersebut juga sesuai dengan salah satu konsep dari teori interaksi simbolik yaitu diri (self) di mana generasi milenial mendefinisikan dirinya sebagai individu yang percaya diri, kreatif, menyenangkan, asik, dan suka berbagi informasi berdasarkan tanggapan dari pengguna media sosial Instagram lainnya melalui likes dan komentar yang diberikan.

Mead juga menyebutkan, seseorang memiliki kemampuan untuk menjadi subyek dan obyek. Subyek bersifat spontan, impulsif, dan kreatif, sedangkan obyek bersifat reflektif dan lebih peka secara sosial. Hal tersebut sesuai dengan pernyataan informan 5: persepsi yang dibentuk adalah anak muda sebagai obyek dibanding suatu subyek karena kalau anak muda dianggap obyek, maka akan diperlakukan sebagai obyek seperti obyek iklan, obyek produk. Tapi kalau anak muda dipersepsikan sebagai subyek, dia akan dilihat sebagai seorang individu yang mampu melakukan perubahan.

Pembentukan citra diri generasi milenial juga dibentuk oleh masyarakat melalui terpaan media sehingga hal tersebut sesuai dengan salah satu konsep pada teori interaksi simbolik yaitu masyarakat (society). Mead mengemukakan, masyarakat merupakan sebuah jaringan interaksi sosial di mana suatu anggota masyarakat memberikan makna terhadap tindakan mereka sendiri diikuti oleh simbol-simbol.

Generasi Milenial sangat luas di Indonesia sehingga banyak persepsi yang terbentuk mengenai generasi ini melalui media. Bagi orang awam, generasi milenial adalah generasi yang instan, mau enaknya saja, tidak sopan, dan lain sebagainya. Namun tidak semua generasi milenial seperti itu sehingga tercipta stereotype general yang menyatakan generasi milenial adalah generasi yang hidup di era teknologi.

Dari hasil penelitian, citra diri yang dibentuk oleh generasi milenial menggunakan media sosial Instagram tidak sebagai ladang pekerjaan, adalah seorang individu yang unik, kreatif, percaya diri, dan connected. Mereka mampu berinteraksi dengan orang lain melalui media sosial. Hal tersebut sesuai dengan penelitian Nugraha dan Akbar (2018) yang menunjukkan para informan dari komunitas Kaskus menjadi pengguna aktif media sosial Instagram karena berbagai faktor yang melatarbelakangi, salah satunya adanya fasilitas pendukung yang memudahkan mereka untuk mengakses dan melakukan interaksi di Instagram.

Para informan generasi milenial menggunakan media sosial sebagai alat untuk menyampaikan suatu pesan kepada public. Hal tersebut senada dengan fungsi dari media sosial yang diungkapkan Alexis S. Tan (dalam Nurudin, 2013) yaitu sebagai pemberi informasi dan untuk mempersuasi.

Instagram merupakan salah satu platform yang paling sering digunakan oleh generasi milenial. Generasi milenial menggunakan beberapa fitur yang disediakan oleh Instagram seperti instagram story, comment, dan direct message untuk berkomunikasi dengan para pengikutnya. Generasi milenial 
menggambarkan citra dirinya di media sosial Instagram seperti kehidupan sehari-harinya. Hal tersebut sesuai dengan konsep diri atau self-concept yang merupakan gambaran siapakah diri individu tersebut sebenarnya. Ini juga senada dengan penelitian Sakti dan Yulianto (2018) yang mengatakan remaja pengguna media sosial Instagram secara aktif akan mengkonstruksi dirinya melalui persepsi dari orangorang di sekitarnya.

Citra diri itu terbentuk tergantung pada konstituen mana yang terlibat sehingga suatu individu atau kelompok dapat memiliki banyak citra yang berbeda. Begitu juga pada generasi milenial. Banyaknya media yang melakukan stereotype pada generasi ini mengarah kepada citra diri yang negatif yaitu generasi yang mau enaknya saja, generasi instan, generasi rebahan, generasi yang tidak mau susah, tidak sopan, tidak respect dengan orang-orang di sekitarnya. Namun sebenarnya generasi milenial ini memiliki citra yang positif yaitu percaya diri, kreatif, dan anak-anak muda yang berdampak di berbagai bidang. Hal tersebut senada dengan penelitian Alvara Research Center (2014) yang mengemukakan bahwa generasi milenial memiliki tiga karakter 3C (Creative, Confidence, Connected).

Creative, generasi ini terbiasa berpikir out of the box, memiliki ide-ide dan gagasan. Confidence, generasi milenial memiliki tingkat kepercayaan diri yang tinggi dan berani mengungkapkan pendapatnya. Connected, merupakan salah satu karakter yang dimiliki oleh generasi milenial karena generasi ini pandai dalam berinteraksi dengan teman-temannya melalui media sosial.

Karakter connected ini juga senada dengan penelitianAyun (2015) yang mengatakan, para remaja menggunakan media sosial karena ingin menjalin komunikasi dengan teman-teman mereka. Remaja juga mencoba membentuk sebuah citra yang positif di media sosialnya seperti individu yang terlihat pintar dan senang menunjukan hobinya.

\section{KESIMPULAN}

Media sosial Instagram merupakan sebuah platform yang digunakan generasi milenial dalam membentuk citra diri. Selain Instagram, feed yang digunakan untuk membentuk citra diri, Instagram Story juga menjadi salah satu feature yang digunakan generasi milenial dalam membentuk citra dirinya. Publik dengan mudah menilai seseorang hanya dalam waktu lima belas detik melalui Instagram Story.

Dalam membentuk citra dirinya di media sosial Instagram, generasi Milenial menciptakan simbolsimbol yang menjadi ciri khas dirinya seperti tone warna pada foto-fotonya. Gaya bahasa yang digunakan adalah gaya bahasa yang santai atau casual sehingga terbentuk sebuah citra diri yaitu generasi milenial merupakan seorang individu yang unik, kreatif, percaya diri, dan connected di mana mereka mampu berinteraksi dengan orang lain atau masyarakat melalui media sosial.

\section{DAFTAR PUSTAKA}

Aditya, R. (2015). Pengaruh Media Sosial Instagram Terhadap Minat Fotografi Pada Komunitas Fotografi Pekanbaru. Jurnal Online Mahasiswa, 2(2), 1-14. ISSN: 2355-6919.

Ali, H., \& Purwandi, L. (2017). Millennial Nusantara. Jakarta, Indonesia: PT Gramedia Pustaka Utama. Alvara Research Center. (2014). Generasi Millennial Indonesia: Tantangan dan Peluang Pemuda Indonesia [PDF File]. Retrieved from http://alvara-strategic.com/generasi-millennial-indonesiatantangan-dan-peluang-pemuda-indonesia/

Arifin, C. (2019, Juni 19). Pengguna Media Sosial di Indonesia Terbesar Keempat di Dunia. Retrieved from https://www.tribunnews.com/techno/2019/06/19/pengguna-sosial-media-di-indonesiaterbesar-keempat-di-dunia

Arviana, G. N. (2017, Agustus 3). Gunakan Media Sosial Untuk Membangun Citra Diri. Retrieved from https://muda.kompas.id/baca/2017/08/03/gunakan-media-sosial-untuk-membangun-citra-diri/

Ayun, P. Q. (2015). Fenomena Remaja Menggunakan Media Sosial Dalam Membentuk Identitas. Channel: Jurnal Komunikasi, 3(2), 1-16. doi: http://dx.doi.org/10.12928/channel.v3i2.3270

Badan Pusat Statistik. (2018). Profil Generasi Milenial Indonesia. Jakarta, Indonesia: Kementerian Pemberdayaan Perempuan dan Perlindungan Anak.

Cahyono, A. S. (2016). Pengaruh Media Sosial Terhadap Perubahan Sosial Masyarakat di Indonesia. Jurnal Publiciana,9(1), 140-157. Retrieved from https://journal.unita.ac.id/index.php/publiciana/article/view/79

Chaplin, J. P. (2011). Kamus Lengkap Psikologi. Jakarta, Indonesia: PT. Rajagrafindo Persada. 
Creswell, J., W. (2014). Research Design Qualitative, Quantitative, and Mixed Method Approaches (Eds. 4). Thousand Oaks, CA: Sage Publications Inc.

Dwilestari, G., \& Fithrah, D. S. A. (2018). Motif Penggunaan Aplikasi Bigo Live Di Kalangan Mahasiswa Jurusan Ilmu Komunikasi Universitas Telkom Motif of Using Bigo Live Application Among Students of Communication Sciences Major in Telkom University Broadcaster Bigo Live disebut juga Bigo Host Bi. 3(1), 67-80. doi: http://jurnal.unpad.ac.id/manajemenkomunikasi/article/view/12901/pdf

Loretta, D. (2015). It's Me! Superbrand Diri Untuk Jadi Beda (H. Munandar). Jakarta, Indonesia: Lintas Mata.

Mailanto, A. (2016, Januari 14). Pengguna Instagram di Indonesia Terbanyak, Mencapai 89\%. Retrieved from https://techno.okezone.com/read/2016/01/14/207/1288332/penggunainstagram-di-indonesia-terbanyak-mencapai-89

Mutia, T. (2017). Generasi Milenial, Instagram Dan Dramaturgi: Suatu Fenomena Dalam Pengelolaan Kesan Ditinjau Dari Perspektif Komunikasi Islam. Garuda, 41(2), 240-251. doi: http://dx.doi.org/10.24014/an-nida.v41i2.4656

Nasrullah, R. (2015). Media Sosial Perspektif Komunikasi, Budaya, dan Sosioteknologi. Bandung, Indonesia: Simbiosa Rekatama Media.

Nugraha, B., \& Akbar, M. F. (2018). Perilaku Komunikasi Pengguna Aktif Instagram. Jurnal Manajemen Komunikasi, 2(2), 95-101. doi: https://doi.org/10.24198/jmk.v2i2.21330

Nurudin. (2013). Pengantar Komunikasi Massa. Jakarta, Indonesia: PT. Rajagrafindo Persada

Pramono, Y. (2019, Mei 16). APJII: Jumlah Pengguna Internet di Indonesia Tembus 171 Juta Jiwa. Retrieved from https://tekno.kompas.com/read/2019/05/16/03260037/apjii-jumlah-penggunainternet-di-indonesia-tembus-171-juta-jiwa

Safitri, Y. \& Ramadanty, S. (2019). Strategi Keterlibatan Key Opinion Leaders dalam Kampanye Public Relations di Indonesia. Jurnal Warta Ikatan Sarjana Komunikasi Indonesia. 2(2). 88-96. doi: https://doi.org/10.25008/wartaiski.v2i02.35.

Sakti, B. C., \& Yulianto, M. (2018). Penggunaan Media Sosial Instagram Dalam Pembentukan Identitas Diri Remaja. Interaksi Online. 6(4). 490-501. Retrieved from https://ejournal3.undip.ac.id/index.php/interaksi-online/article/view/21950

Srinanda, E. (2019). Membangun Generasi Milenial Melalui PPK Sesuai Dengan Nilai-Nilai Pancasila. Jurnal Pendidikan: Riset\&Konseptual, 3(4), 305-402. doi: 10.28926/riset_konseptual.v3i4.160

Sugiyono. (Eds. 23). (2016). Metode Penelitian Kualitatif, Kuantitatif, dan R\&D. Bandung, Indonesia: CV Alfabeta.

Wahyudi, U., Ronauli, M., Elita, F. dan Mirawati, I. (2016). Hubungan antara Pesan Kampanye 9 Aksi Ramah Lingkungan di Akun Twitter Earth Hour Bandung dengan Sikap Followers Aktif Terhadap Gaya Hidup Ramah Lingkungan. Jurnal Manajemen Komunikasi. Vol 1 No.1. 125144. doi: https://doi.org/10.24198/jmk.v1i1.11017

We are Social. (2019). Digital 2019: Essential Insights In to How People Around The World Use The Internet, Mobile Devices, Social Media, and E-Commerce [PDF File]. Retrieved from https://wearesocial.com/global-digital-report-2019

West, R., \& Turner, L. H. (Eds. 3). (2008). Pengantar Teori Komunikasi: Analisis dan Aplikasi Buku 1 (B. Marswendy). Jakarta, Indonesia: Salemba Humanika.

Young, S. J., Sturts, J. R., Ross, C. M., \& Kim, K. T.(2013). Generational Differences and Job Satisfaction in Leisure Services. Managing Leisure, 18(2), 152-170. doi: https://doi.org/10.1080/13606719.2013.752213

Yunus, U. \& Gustina, G. (2018). Pola Penyebaran Pesan Melalui Akun Facebook pada Karyawan Generasi Milenial di PT. XXX Indonesia. Jurnal Warta Ikatan Sarjana Komunikasi Indonesia. Vol. 1 No. 02. 75-81. doi: https://doi.org/10.25008/wartaiski.v1i02.20

Yuswohady. (2019). Millennials Kill Everything. Jakarta, Indonesia: PT Gramedia Pustaka Utama. 